\title{
Coronary Artery Bifurcation Angle Degree; Bifurcation Lesion Development and the Prognostic Impact
}

\author{
AHMED GAAFAR, M.D.*; ALAA MOHAMMED, M.Sc.** and MOUSTAFA ABDEL KAWI, M.D.*** \\ The Department of Cardiology, Faculty of Medicine, Helwan University* and Mabarret Misr El-Kadima Hospital** and \\ The Department of Radio Diagnosis, Faculty of Medicine, Helwan University***, Cairo, Egypt
}

\begin{abstract}
Background: Coronary artery bifurcation lesion is one of the challenges in coronary arteries revascularization. Hemodynamic factors, as bifurcation angle is widely recognized for its involvement in atherosclerotic plaque formation.

Aim of Work: Our aim of this study was to detect the effect of coronary artery bifurcation angle degree on the development of bifurcation atherosclerosis using Computed Tomography Coronary Angiography [CTCA] and its prognostic impact.

Patients and Methods: The study was included 221 patients having low and intermediate pretest probability for Coronary Artery Disease [CAD]. Coronary arteries were investigated with CTCA for detection of bifurcation lesions, assessment of bifurcation angle and bifurcation lesion type, then 1 year follow-up period for Acute Coronary Syndrome (ACS).
\end{abstract}

Results: 138 patients were males $(62 \%)$ and 83 were females $(38 \%)$. The meanage group was $55.7 \pm 9.8$ years old Bifurcation lesions were higher at LAD-LCx (125 patients, $56.5 \%$ ) than at LAD-major diagonal (104 patients, 47\%), than at LCx-OM (56 patients, $25 \%$ ) ( $p$-value $<0.0001)$. At LADLCx sites there were higher bifurcation angles in patients with atherosclerotic bifurcation lesions than patients without bifurcation lesions $\left(77.32^{\circ} \pm 18.1^{\circ}\right.$ vs. $62.24^{\circ} \pm 18.2^{\circ}, p$-value 0.001 ), while there was no statistically significant difference as regard bifurcation angels at LAD-diagonal and $\mathrm{LCx}-\mathrm{OM}$ bifurcation sites. There was no relation between bifurcation angle and type of atherosclerotic plaque at the three studied bifurcation sites. Patients with wider bifurcation angels regardless lesions severity or management protocol had higher rates of ACS.

Conclusion: A strong relation between LM bifurcation angel and the development of atherosclerotic lesions was noted, where wider bifurcation angles are more prone for atherosclerotic lesions, and more prone to develop ACS.

Key Words: CT coronary angiography - CAD - Bifurcation lesion - Bifurcation angel-ACS - Plaque type.

Correspondence to: Dr. Ahmed Gaafar, E-Mail: Gaafar911@ @otmail.com

\section{Introduction}

THE National Center for Health Statistics [NCHS] had reported cardiovascular diseases as the major cause of death in USA, occurring in all ethnic populations involving both genders. It is considered the cause of $25 \%$ of deaths in USA in 2011 which accounted more than 600.000 deaths (Wolk, 2014 \#48) [1].

During coronary intervention, one of challenges that face any interventionist is bifurcation coronary artery lesions due to its complex nature and higher complication incidence. It is accounting about $20 \%$ of all Coronary Artery Disease (CAD) cases at coronary catheterization [2]. The technical difficulties inherent in the treatment of bifurcation lesions, associated with their lower success and higher complication rates compared with non-bifurcation lesions have always been the object of intense research activity [3].

\footnotetext{
List of Abbreviations:

CAD : Coronary Artery Disease.

CA : Coronary Angiography.

IHD : Ischemic Heart Disease.

CTCA : Computed Tomography Coronary Angiography.

MSCT : Multi-slice Computed Tomography.

CT : Computed Tomography.

LM : Left Main Coronary Artery.

LAD : Left Anterior Descending Coronary Artery.

LCx : Left Circumflex Coronary Artery.

OM : Obtuse Marginal Coronary Artery.

MB : Main Branch Coronary Artery.

SD : Side Branch Coronary Artery.

PCI : Percutaneous Coronary Intervention.

CABG : Coronary Artery Bypass Graft.

MPR : Multiplanar Reconstruction.

MIP : Maximal Intensity Projection.

LDL : Low Density Lipoproteins.

ACS : Acute Coronary Syndrome.
} 
The formation of athermanous plaques can be explained as a response of the arterial wall to an injury which defined atherosclerosis as chronic inflammatory reaction to endothelial injury [4]. It is an interactive multi factorial disease [5].

The atherosclerosis development is higher at coronary artery bifurcation sites due multiple interacting factors, as increased endothelial shear stress, as well as, specific flow dynamics which lead to endothelial injury [6]. Flow characteristics at bifurcation sites depends on the anatomy of coronary bifurcations, such as diameters of the Main Vessel (MV) and the Side Branches (SB), atherosclerotic plaque burden in the proximal and distal part of the MV and the SB, and bifurcation angle [7]. The flow induced endothelial shear stress and subsequent changes lead to alteration in the patterns of gene expression which also mediate the transcription activation of pro-atherogenic factors [8]. Shear stress has an essential role in plaque formation and also atherosclerosis progression [9]

In previous pathologic study, they found coronary atherosclerosis mainly involves the lateral wall of artery bifurcations opposite to carina, which corresponds to low and oscillatory endothelial shear stress areas [10].

The development of Multi Slice Computed Tomography (MSCT) and improvement of imaging quality for coronary artery imaging made MSCT and acceptable alternative to invasive coronary angiography for coronary artery imaging and assessment of significant coronary artery disease with high accuracy [11].

\section{Aim of the work:}

The main aim of the study was to detect the impact of coronary artery bifurcation angle degree on the development of coronary artery bifurcation atherosclerosis using MSCT Coronary Angiography (MSCTCA), and to find its prognostic impact.

\section{Patients and Methods}

This study included 221 patients (138 males, 83 females), having low and intermediate pretest probability for CAD. They were referred from Helwan Health Insurance Cardiac Committee to Nile-Scan Radiology Centers in the period 5/2019 and $11 / 2020$, for non-invasive evaluation of the coronary arteries by MSCTCA and revealed coronary artery atherosclerotic bifurcation lesions.

Twelve months follow-up study was performed for all patients for incidence of new ACS events.
Exclusion criteria: Previous Percutaneous Coronary Intervention (PCI) at bifurcation sites or Coronary Artery Bypass Graft (CABG) surgery, patients with known allergy or hypersensitivity to contrast media, irregular heart rhythms (e.g. atrial fibrillation), obese patients (body mass index $>35 \mathrm{~kg} / \mathrm{m}^{2}$ ), elevated calcium score (calcium score $>800$ ), renal insufficiency with serum creatinine greater than $1.5 \mathrm{mg} / \mathrm{dl}$, inability to follow breath holding instructions and pregnancy.

Pretest probability was calculated as regard chest pain, sex, and age as it was demonstrated at (Table 1) [12].

Table (1): Estimation of pretest probability.

\begin{tabular}{lllll}
\hline $\begin{array}{l}\text { Age } \\
\text { (years) }\end{array}$ & Gender & $\begin{array}{c}\text { Typical } \\
\text { angina }\end{array}$ & $\begin{array}{c}\text { Atypical } \\
\text { angina }\end{array}$ & $\begin{array}{c}\text { Mon-anginal } \\
\text { chest pain }\end{array}$ \\
\hline $30-39$ & $\begin{array}{l}\text { Men } \\
\text { Women }\end{array}$ & $\begin{array}{l}\text { Intermediate. } \\
\text { Intermediate }\end{array}$ & $\begin{array}{l}\text { Intermediate } \\
\text { Low }\end{array}$ & $\begin{array}{l}\text { Low } \\
\text { Low }\end{array}$ \\
40-49 & $\begin{array}{l}\text { Men } \\
\text { Women }\end{array}$ & $\begin{array}{l}\text { High } \\
\text { Intermediate }\end{array}$ & $\begin{array}{l}\text { Intermediate } \\
\text { Low }\end{array}$ & $\begin{array}{l}\text { Intermediate } \\
\text { Low }\end{array}$ \\
50-59 & $\begin{array}{l}\text { Men } \\
\text { Women }\end{array}$ & $\begin{array}{l}\text { High } \\
\text { Intermediate }\end{array}$ & $\begin{array}{l}\text { Intermediate } \\
\text { Intermediate }\end{array}$ & Intermediate \\
& Men & High & Intermediate & Intermediate \\
& Women & High & Intermediate & Intermediate \\
\hline
\end{tabular}

Multi-slice CT coronary angiography protocol:

The studies were done at heart rate $<70 \mathrm{~b} / \mathrm{m}$ with 10 seconds breathe holding.

Scanning: A retrospectively Electrocardiographic (ECG)-gated scan without contrast media was performed to determine the total calcium burden of the coronary tree.

Injection: $70-90 \mathrm{ml}$ of contrast was injected though the IV line followed by a $50 \mathrm{ml}$ of saline chaser, at rate $5-6 \mathrm{ml} / \mathrm{sec}$ for both the contrast and the saline but injection speed rate was $7 \mathrm{ml} / \mathrm{sec}$ in patient with large IV access and patient with high BMI.

Scan protocol and parameters: We used the 256-slice MSCT row scanner Brilliance iCT; (Philips Medical Systems; Eindhoven, Netherland). Scanning parameters were $256 \times 0.625 \mathrm{~mm}$ collimation, tube rotation time of $400 \mathrm{msec}$, tube voltage of $120 \mathrm{KV}$ (increased to $140 \mathrm{KV}$ in obese patients) and current of $440-550 \mathrm{~mA}$. The field of view was $25 \mathrm{~cm}$ with an image matrix of 512 X 512 pixels. Scanning direction was cranio-caudal.

Image reconstruction: The reconstructed axial images at different points of the cardiac cycles 
were sent to an off-line workstation (Vitrea 2, vital images, USA). A slice thickness of $0.6 \mathrm{~mm}$ reconstructions was used. Axial images, three dimensional volume rendering reconstruction, Multiplanar Reconstruction (MPR), Maximal Intensity Projection (MIP) and volume rendering techniques were used.

Analysis of coronary artery lesions: A systematic analysis of a coronary artery MSCT study was done for detection and localization of coronary artery lesions at any of the three major bifurcations of the left coronary artery, carefully avoiding sections or interposed structures with potential image artifacts. We had evaluated the composition and morphology of the lesions, and characterized them based on CT attenuation, where calcified plaques indicated plaques with high density, noncalcified plaques had lower density compared with the contrast enhanced vessel lumen, mixed plaques indicated plaques with non-calcified and calcified elements within a single plaque or within coronary artery segment [13]. Qualitative and quantitative assessment of the obstruction degree of the vessel caused by the lesion was done. The most sever

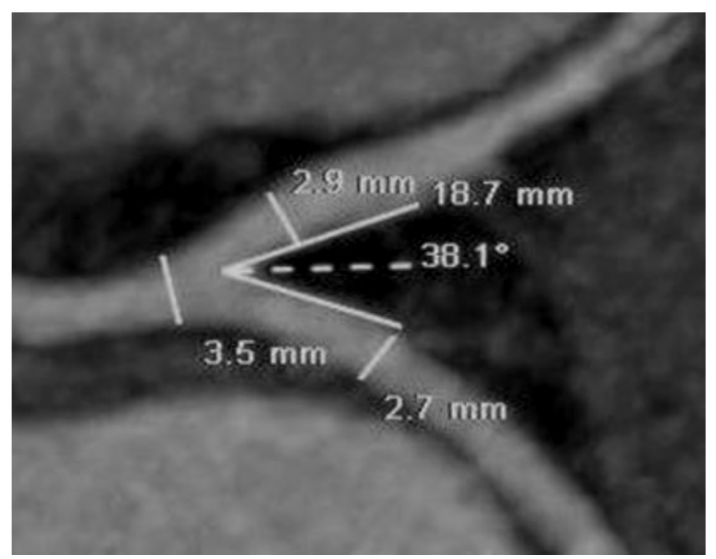

(A)

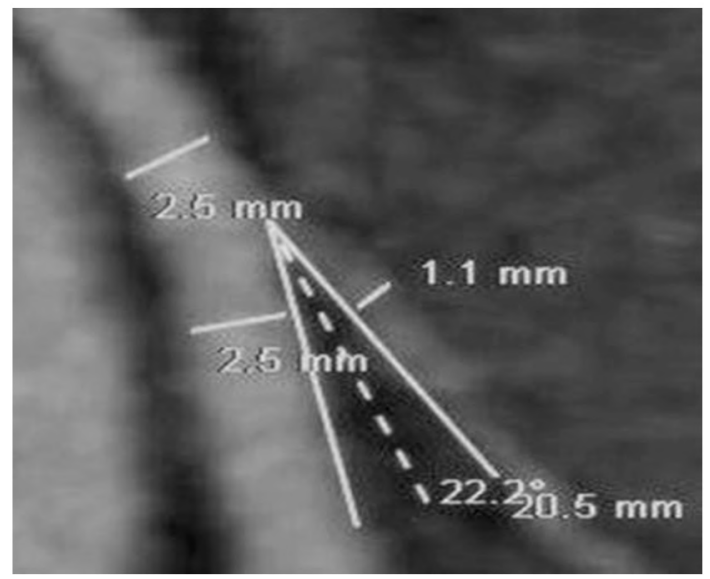

(C) lesion was considered in the main vessel or any one of the two daughters [14].

Stenosis was considered as a non-significant if less than $50 \%$ of the vessel lumen, including mild and moderate degrees of obstruction, while significant stenosis was equal or more than $50 \%$, including critical sub-occlusive and occlusive lesions [15].

Measurement of the major bifurcation angles in the left coronary arterial system: 3D volume rendering and curved planar reformatted images were generated for the assessment of the 3 major bifurcation angles in the left coronary artery including (LAD-LCx), (LAD-major diagonal artery) and (LCx-OM). The MPR view (where the angulation between the main vessel and SB was maximal) was used to determine the bifurcation angle values. The angle was delineated by two centerline vectors drawn along the initial 5-mm course of the distal main vessel and SB, respectively. Only diastolic data sets were used for BA measurements. Examples of angle measurements are shown at Fig. (1), and examples of bifurcation lesions at the three studied sites are shown at Fig. (2).

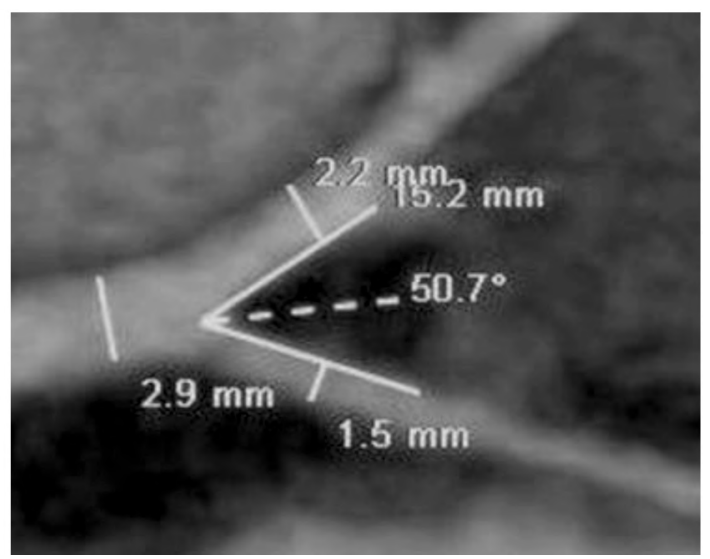

(B)

Fig. (1): Left coronary artery bifurcation angles and dimensions measurement by MSCT in a normal individual. Multi-planer reconstructions were rendered exactly in the plane described by the main vessel and side branch at the bifurcation site. (A) Angle between LAD-LCx (38.10). (B) Angle between LAD-diagonal (50.70). (C) Angle between LCX-OM (22.20).

\footnotetext{
MSCT : Multi-Slice Computed Tomography.

LAD : Left Anterior Descending Artery.

LCx : Left Circumflex Artery.

OM : Obtuse Marginal

Diagonal : Diagonal Artery.
} 


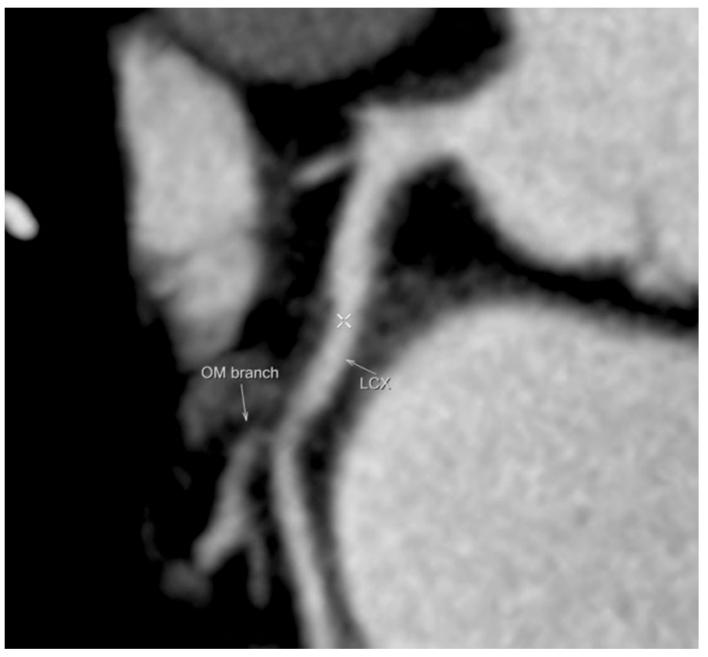

(A)

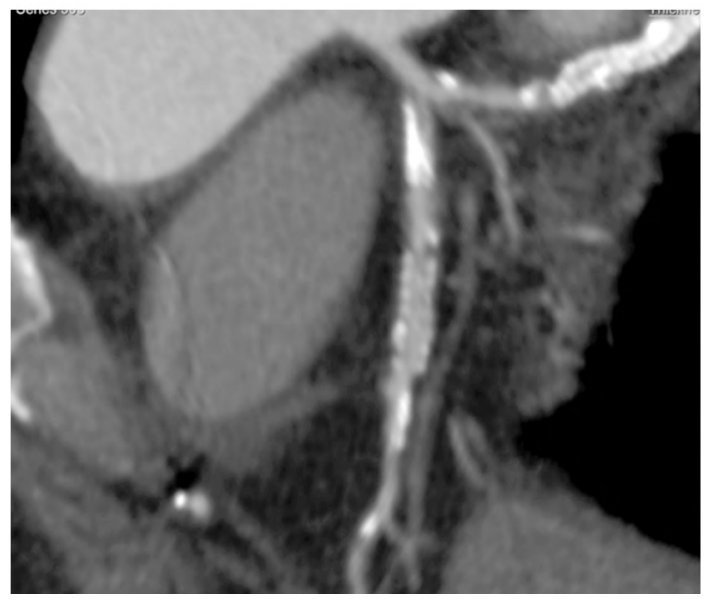

(C)

Statistical analysis of data; Descriptive statistics: Data were statistically described in terms of mean \pm Standard Deviation ( \pm SD), median and range, or frequencies (number of cases) and percentages when appropriate. Analytical statistics: Student $t$-test: Was used for independent samples in comparing 2 groups when normally distributed. Mann Whitney U-test: Was used for independent samples in comparing 2 groups when not normally distributed. ANOVA (one-way analysis of variance) test: Was used for comparison of normally distributed numerical variables between more than two groups. Kruskal Wallis test: Was used for comparison of non-normal numerical variables between more than two groups. Accuracy was represented using the terms sensitivity, and specificity. Multivariable analysis with Chi-Square test was done. Statistical significance was defined as: $p$-value $>0.05$ : Insignificant, $p$-value <0.05: Significant and $p$-value $<0.01$ : Highly significant. All statistical calculations were done using computer program SPSS (Statistical Package for the Social Science; SPSS Inc., Chicago, IL, USA) release 15 for Microsoft Windows (2006).

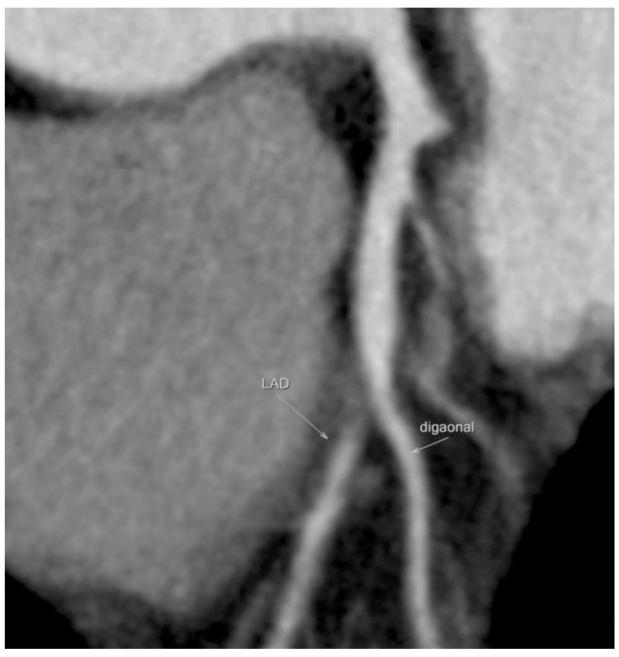

(B)

Fig. (2): (A) LCx-om; a non-calcific plaque in mid $1 C x$ seen extending along the ostial to proximal segment of om causing significant lumen stenosis. (B) LAD-diagonal; a proximal LAD showed non calcific plaque extending along the ostial diagonal branch causing significant lumen stenosis. (C) LM bifurcation; the distal LM shows a non-calcific plaque causing mild lumen stenosis and seen extending along the ostial to proximal LAD showing partially calcific plaque causing significant lumen stenosis and extended to ostial to proximal $\mathrm{lCx}$ causing partially calcific significant lesion.

\section{Results}

Of the subjects who are referred with low and intermediate probability for CAD for CTCA assessment in the study period, $221(24.6 \%)$ revealed coronary artery bifurcation lesions, 128 patients $(58 \%)$ had intermediate pretest probability for CAD and 93 patients $(42 \%)$ had low pretest probability. 138 of the studied patients were males $(62 \%)$ and 83 were females (38\%), with age ranged between 48 and 76 years; mean age $60.7 \pm 9.8$ years.

We found $65.5 \%$ of the patients were hypertensive, $53.5 \%$ of them had dyslipidemia, $54 \%$ were smokers, $42.3 \%$ were diabetics and $41.1 \%$ had a family history of ischemic heart disease. There were no significant differences between low and intermediate pretest probability groups regards clinical and laboratory data except in LDL level and incidence of DM where both were significantly higher in intermediate probability group ( $95 \pm 35$ vs. $125 \pm 45, p 0.01)$ and (32 patients vs. 61 patients, $p 0.045$ ) respectively (Table 2 ). 
There was a statistically significant difference as regard prevalence of significant CA bifurcation lesions between both groups, where it was higher in intermediate probability group (39.8\% vs. $55.5 \%$, $p$ 0.02) Table (2).

The mean degree of LAD-LCx bifurcation angle was $71.4^{\circ} \pm 18.5^{\circ}$ with range $26^{\circ}-132^{\circ}$. The mean degree of LAD-diagonal bifurcation angle was $49.5^{\circ} \pm 18.7^{\circ}$ with range $17^{\circ}-137^{\circ}$. The mean degree of the LCx-OM bifurcation angle was $44.6^{\circ} \pm 21.4^{\circ}$ with range $15^{\circ}-128^{\circ}$ (Table 3 ).

Bifurcation lesion prevalence was higher at LAD-LCx (125 patients, 56.5\%) than at the LADdiagonal bifurcation (84 patients, 38\%), than at the LCx-OMbifurcation (56 patients, 25\%) ( $p$ value $<0.0001$ ) (Table 3 ).

There were no significant differences as regard atherosclerotic plaque type found at different bifurcation lesion sites (Table 3).

As regard relation between bifurcation angel degree and development of atherosclerotic plaque, at LAD-LCx site there were wider bifurcation angles in patients with atherosclerotic bifurcation lesions than patients without bifurcation lesions $\left(77.32^{\circ} \pm 18.1^{\circ}\right.$ vs. $62.24^{\circ} \pm 18.2^{\circ}, p$-value 0.001$)$. While there were no statistical significant differences at LAD-diagonal and LCX-OM bifurcation sites, $\left(49.5^{\circ} \pm 16.5\right.$ vs. $\left.44.3^{\circ} \pm 15.8\right)$ and $\left(41.3^{\circ} \pm 3\right.$ vs. $43.3^{\circ} \pm 19.4$ ) respectively (Table 3 ).

There was no relation between bifurcation angle and type of atherosclerotic plaque at the three studied bifurcation sites (Table 3 ).

As regard patients with significant CAD bifurcation lesions, 21 patients (19\%) were managed with medical treatment due to patients' preference, while 19 patients $(17.4 \%)$ underwent $\mathrm{CABG}$, and 69 patients $(63.3 \%)$ were treated with PCI and stenting.

During the one year follow-up, as regards patients with non-significant bifurcation lesion by CTCA (113 patients), the patients who developed ACS events (17 patients, 15\%) had wider bifurcation angles than those who didn't developed ACS events (96 patients, $85 \%),\left(70.88^{\circ} \pm 10.9\right.$ vs. $62.66^{\circ} \pm$ 13.8 , respectively, $p$ 0.0002). As regards medically treated patients with significant bifurcation lesions (21 patients, 19\%), patients who developed ACS events; 4 patients $(19 \%)$ had wider bifurcation angle than those who didn't; 17 patients $(81 \%)$, $\left(69.25^{\circ} \pm 9.9\right.$ vs. $57.7^{\circ} \pm 8.6$, respectively, $\left.p 0.016\right)$. Regards PCI treated patients with significant bifurcation lesions (69 patients, 63.3\%), patients who developed ACS events (3 patients, 4\%) had wider bifurcation angles than those who didn't; 66 patients $(96 \%),\left(80.33^{\circ} \pm 8.2\right.$ vs. $67.2^{\circ} \pm 7.8$, respectively, $p$ 0.003).

By multivariate regression analysis we found that bifurcation angle degree is an independent factor for development of ACS (coefficient 0.1230, slandered error $0.0291, p$-value 0.0001 , odds ratio 1.1309).

As regards, DM, HTN, dyslipidemia, gender, smoking, Optimal Medical Treatment (OMT) and age, there were no statistical significant differences between ACS group and asymptomatic group.

Q: Why didn't you identify a cut off point for angle bifurcation?

A: Actually, we didn't have this idea and the statistician didn't suggest this test.

Table (2): Clinical data and CAD distribution in studied groups.

\begin{tabular}{|c|c|c|c|}
\hline No $(\%)$ & $\begin{array}{l}\text { Low pretest probability } \\
\qquad 93(42 \%)\end{array}$ & $\begin{array}{c}\text { Intermediate pretest } \\
\text { probability } 128(58 \%)\end{array}$ & $\begin{array}{c}p- \\
\text { value }\end{array}$ \\
\hline $\mathrm{BP}$ & $110 \pm 20$ & $130 \pm 20$ & NS \\
\hline HR & $62 \pm 7$ & $61 \pm 6$ & NS \\
\hline LDL & $95 \pm 35$ & $125 \pm 45$ & 0.01 \\
\hline S.creat & $1.1 \pm 4$ & $1.3 \pm 3$ & NS \\
\hline DM & 32 patients & 61 patients & 0.045 \\
\hline HTN & 41 patients & 59 patients & NS \\
\hline Smoker & 55 patients & 64 patients & NS \\
\hline CAD & 59 patients $(63.5 \%)$ & 90 patients $(70.3 \%)$ & NS \\
\hline Sig. BF. lesion & 13 patients $(14 \%)$ & 47 patients $(36.7 \%)$ & 0.0003 \\
\hline Significant bifurcation lesion $\%$ & 39.8 & 55.4 & 0.02 \\
\hline : Blood Pressure. & HTN & \multirow{4}{*}{\multicolumn{2}{|c|}{$\begin{array}{l}\text { : Hypertension. } \\
\text { : Coronary Artery Disease. } \\
\text { : Significant Bifurcation lesion. } \\
\text { : Non-Significant. }\end{array}$}} \\
\hline HR $\quad$ : Heart Rate. & CAD & & \\
\hline LDL : Low Density Lipoprotein. & Sig. BF. les & & \\
\hline S.creat : Serum creatinine. & & & \\
\hline
\end{tabular}


Table (3): Demonstrates mean Bifurcation Angels (BA), comparison between bifurcation angles in patients with Bifurcation Lesions (BL) and patients without BL, distribution of different types of plaques and the relation between plaque type and BA at bifurcation sites, also showed prevalence of BL at bifurcation sites.

\begin{tabular}{|c|c|c|c|}
\hline & LAD, LCx & LAD, Diag & $\mathrm{LCx}, \mathrm{OM}$ \\
\hline Bifurcation angle (mean $\pm \mathrm{SD}$ ) & $71.4^{\circ} \pm 18.5^{\circ}$ & $49.5^{\circ} \pm 18.7^{\circ}$ & $44.6^{\circ} \pm 21.4^{\circ}$ \\
\hline $\begin{array}{l}\text { Type of bifurcation lesion No (\%): } \\
\text { Non-calcific } \\
\text { Calcific } \\
\text { Mixed } \\
p \text {-value }\end{array}$ & $\begin{array}{l}20(17 \%) \\
53(41.6 \%) \\
52(41.4 \%) \\
\text { NS }\end{array}$ & $\begin{array}{l}17(16.3 \%) \\
43(41.3 \%) \\
44(42.3 \%) \\
\text { NS }\end{array}$ & $\begin{array}{l}10(17.85 \%) \\
31(55.4 \%) \\
15(26.75 \%) \\
\text { NS }\end{array}$ \\
\hline $\begin{array}{l}\text { Bifurcation angle (mean } \pm S D) \text { : } \\
\text { Patients with bifurcation lesion } \\
\text { Patients without bifurcation lesion } \\
p \text {-value }\end{array}$ & $\begin{array}{l}77.32^{\circ} \pm 18.1 \\
62.24^{\circ} \pm 18.2 \\
0.001\end{array}$ & $\begin{array}{l}49.5^{\circ} \pm 16.5 \\
44.3^{\circ} \pm 15.8 \\
\text { NS }\end{array}$ & $\begin{array}{l}41.3^{\circ} \pm 3 \\
43.3^{\circ} \pm 19.4 \\
\text { NS }\end{array}$ \\
\hline $\begin{array}{l}\text { Type of bifurcation lesion vs bifurcati } \\
\text { Non-calcific } \\
\text { Calcific } \\
\text { Mixed } \\
p \text {-value }\end{array}$ & $\begin{array}{l}75^{\circ} \pm 21 \\
72.4^{\circ} \pm 20 \\
75.2^{\circ} \pm 21 \\
\text { NS }\end{array}$ & $\begin{array}{l}50^{\circ} \pm 11.4 \\
48.5^{\circ} \pm 12 \\
43.6^{\circ} \pm 31.1 \\
\text { NS }\end{array}$ & $\begin{array}{l}75.2^{\circ} \pm 21 \\
46^{\circ} \pm 19 \\
44.3^{\circ} \pm 30.7 \\
\text { NS }\end{array}$ \\
\hline $\begin{array}{l}\text { Prevalence of bifurcation lesion: } \\
\text { No }(\%) \\
p \text {-value }\end{array}$ & $125(56.5 \%)$ & $\begin{array}{l}84(47 \%) \\
0.0001\end{array}$ & $56(25 \%)$ \\
\hline
\end{tabular}

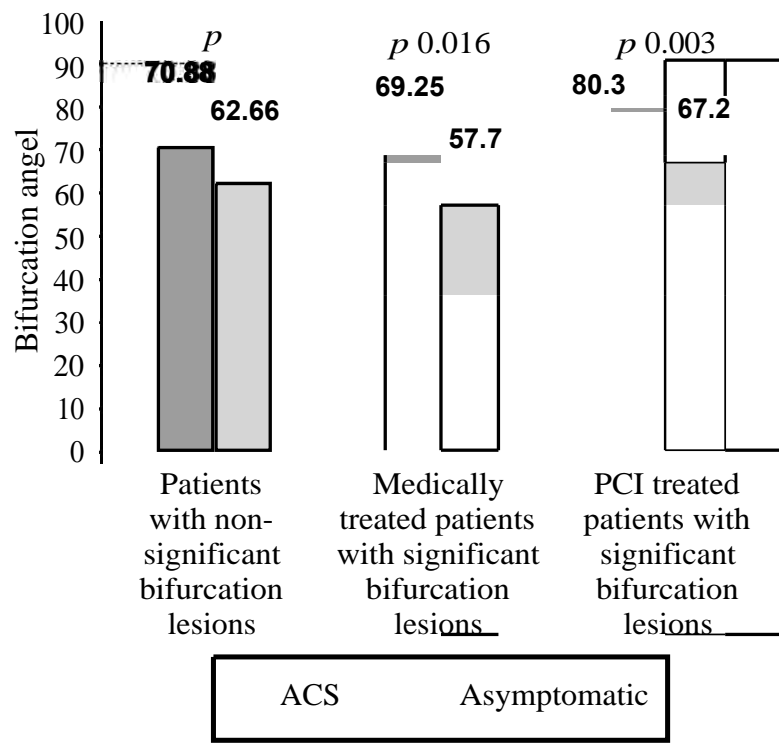

Fig. (3): Comparison of bifurcation angel degree as regards the prevalence of ACS in patients with significant bifurcation lesions and patients with non-significant bifurcation lesions in one year follow-up.

\section{Discussion}

ACS and patient risk depend on plaque composition and its degree of instability beside the luminal narrowing of the coronary artery. Many studies proved the feasibility and accuracy of MSCT for detection of CAD and also its accuracy for differ- entiation of plaque types into calcific, non-calcific and mixed plaques [16,17]

The bifurcation angle influences the endothelial shear stress which in turn affects the size of atherosclerotic plaque [13]. It was reported that wider bifurcation angles were related to increased flow turbulence and associated to low shear stress and it possibly causes proliferation of atherosclerosis plaques at bifurcation sites [18,19] .

Many Intra-Vascular Ultrasound (IVUS) studies found that atherosclerotic plaques were uncommon in left main coronary, but it was common to find plaques in left coronary artery branches especially at the proximal segments with higher incidence at LAD artery [20]

Previous studies which studied coronary artery bifurcation angles and their nature of distribution concluded that LAD-LCx bifurcation angle of $80^{\circ}$ was a cut off value to find atherosclerotic plaque $[21,22]$

In a study done by Papadopoulou et al., [23] on 33 patients with CAD bifurcation lesions distributed as LAD-diagonal in 14 patients $(42 \%)$ and $\mathrm{LCX}$ OM in 8 patients (24\%) and the remaining bifurcations were in the right coronary artery. They reported that wider bifurcation angles were found in bifurcations with proximal segments atheroscle- 
rosis plaques in comparison with those without $(p=0.002)$ and this in agreement with our study.

Z. Sun and Y. Cao [24] studied 30 patients with suspected coronary artery disease. They found the mean (LAD-LCx) bifurcation angle was 89.1 \pm 13.1 . The mean bifurcation angle in normal left coronary arteries was measured $75.5^{\circ} \pm 19.8^{\circ}$, which was smaller than bifurcation angle in diseased LAD $(p=0.02)$ which was $94^{\circ} \pm 19.7^{\circ}$, and also this is in concordance with our results, but they didn't study other bifurcation angles in this study which was an important limitation.

In a study by Rodriguez-Granillo et al., [17] which included 50 patients, the median LAD-LCx bifurcation angle was $88.5^{\circ}$ (range $68.5^{\circ}-101.4^{\circ}$ ). In 18 patients with normal ostial LAD, 13 (72\%), the bifurcation angle was $<88.5^{\circ}$, while those with LAD disease the bifurcation angle was $\geq 88.5^{\circ}$. In 33 patients with normal ostial LCx, 19 (58\%) had a bifurcation angle $<88.5^{\circ}$, while those with diseased LCx had larger angle $\geq 88.5^{\circ}(p=0.136)$. Also the bifurcation angle of patients with normal LMCA was $<88.5^{\circ}$, while those with diseased LM had bifurcation angle $\geq 88.5^{\circ}(p=0.037)$. They concluded that there was strong relationship between left main bifurcation angle and presence of bifurcation plaque. And this is in line with our study.

In a study based on of 100 human hearts, Reig and Petit studied the hearts of 100 human autopsies and found an average angle of $86.7^{\circ} \pm 28.8^{\circ}$ for patients with LAD-LCx bifurcation lesions [21] Also Pflederer et al., in a study on $100 \mathrm{CAD}$ patients found an average bifurcation angle of $80^{\circ} \pm 27^{\circ}$ [22], and Kawasaki et al., found that LAD-LCx bifurcation lesion angle was $72^{\circ} \pm 22^{\circ}$ in 209 CAD patients [25].

In our study, the incidence of bifurcation lesions was $24 \%$ of patients with CAD which in agreement with Collins et al., how found the incidence about $20 \%$ [26]

Our results are in line with the average bifurcation angle reported by previous studies. The average LAD-LCx bifurcation angle in 221 patients with CAD $(56.5 \%)$ was $74.24^{\circ} \pm 20.14^{\circ}$ and this was wider than the average angle in normal coronaries $(43.5 \%)$ which was $63.14^{\circ} \pm 19.22^{\circ}$, with $p$ value $(0.001)$.

In our study, all major bifurcation angles of the left coronary system (LAD-LCx, LAD-major diagonal and $\mathrm{LCX}-\mathrm{OM}$ ) were investigated and correlation between degree of angulation and development of atherosclerotic plaques was proved only at the bifurcation of LAD-LCx (as described above), where wider bifurcation angels had higher incidence of atherosclerosis, while no relation was found at the bifurcation of LAD-diagonal and at LCx-OM bifurcation sites. We explained the absence of correlation between angle degree and the development of bifurcation lesions at LAD-diagonal and LCX-OM groups due to narrow angels that were found at these sites in the study group and it was one of the study limitation, the results could be different if LAD-LCx and LCx-OM groups had wider angels.

Regards the relation between left coronary artery bifurcation angel and type of atherosclerotic plaques, while Z. Sun and Y. Cao [9] mentioned that they couldn't detect the relationship between bifurcation angle and the type of plaque due to the limited sample size as non-calcified plaques were present only in two patients, but in our study there were sufficient number of patients with different types of atherosclerotic plaque for statistical analysis and we found no relation between bifurcation angle and plaque type.

In our study during the one year follow-up, the patients without significant bifurcation lesions who developed ACS had wider bifurcation angles than asymptomatic ones. The same was found in patients with significant lesions, whether they were managed with medical treatment only or who were managed with PCI plus medical treatment. This means that wider bifurcation angles have worse prognosis than narrower bifurcation angels. This is in agreement with Takao Konishi et al. [27], who concluded that wide LMT-LAD angle is associated with a higher risk of proximal LAD artery disease stenting restenosis. Also Dzavik et al. [28], found that angle $>50^{\circ}$ was an independent predictor of MACE, Collins et al. [26], stated that bifurcation angle $<50^{\circ}$ was associated with better outcomes in the crush/culotte group. Adriaenssens et al., [29] found increasing bifurcation angle was an independent predictor of angiographic restenosis. Chen et al. [30], mentioned that bifurcation angle $B$ was an independent predictor of MACE. Freixa et al., [31], found that bifurcation angle $\angle 50^{\circ}$ was associated with a lower risk of MACE.

\section{Limitations:}

One of the limitations in our study is that no correlation with invasive coronary angiography was performed. The relationship between calcified, non-calcified or mixed plaques with patients' symptoms or cardiac events was not studied. Finally, we didn't investigate the bifurcations of the right coronary artery as they are small sized branches. 


\section{Conclusion:}

There was a strong correlation between LM bifurcation angel and the development of atherosclerotic bifurcation lesions and ischemic events, where wider bifurcation angles were more prone for development of atherosclerotic lesions. ACS events incidence was higher in higher bifurcation angels whether the bifurcation lesions were significant or not and in with different management strategies.

\section{References}

1- NARULA J., NAKANO M., VIRMANI R., KOLODGIE F.D., PETERSEN R., NEWCOMB R., MALIK S., FUSTER V. and FINN A.V.: Histopathologic characteristics of atherosclerotic coronary disease and implications of the findings for the invasive and noninvasive detection of vulnerable plaques. J. Am. Coll. Cardiol., 61: 1041$51,2013$.

2- MAGRO M., GIRASIS C., BARTORELLI A.L., TARANTINI G., RUSSO F., TRABATTONI D., D'AMICO G., GALLI M., GOMEZ JUAME A., De SOUSA ALMEIDA M., SIMSEK C., FOLEY D., SONCK J., LESIAK M., KAYAERT P., SERRUYS P.W. and VAN GEUNS R.J.: Acute procedural and six-month clinical outcome in patients treated with a dedicated bifurcation stent for left main stem disease: The tryton $1 \mathrm{~m}$ multicentre registry. Euro. Intervention, 8: 1259-69, 2013.

3- BUYSSCHAERT I., DUBOIS C.L., DENS J., ORMISTON J., WORTHLEY S., McCLEAN D., OTTERVANGER J.P., MEREDITH I., UREN N., WIJNS W., WHITBOURN R., MEHRAN R., LANSKY A.J., BICHALSKA M., MEIS S. and VERHEYE S.: Threeyear clinical results of the axxess biolimus a9 eluting bifurcation stent system: The diverge study. Euro. Intervention, 9: 573-81, 2013.

4- SAKAKURA K., NAKANO M., OTSUKA F., LADICH E., KOLODGIE F.D. and VIRMANI R.: Pathophysiology of atherosclerosis plaque progression. Heart Lung Circ., 22: 399-411, 2013.

5- PRANAVCHAND R. and REDDY B.M.: Current status of understanding of the genetic etiology of coronary heart disease. J. Postgrad. Med., 59: 30-41, 2013.

6- SOULIS J.V., GIANNOGLOU G.D., CHATZIZISIS Y.S., FARMAKIS T.M., GIANNAKOULAS G.A., PARCHARIDIS G.E. and LOURIDAS G.E.: Spatial and phasic oscillation of non-newtonian wall shear stress in human left coronary artery bifurcation: An insight to atherogenesis. Coron. Artery Dis., 17: 351-8, 2006.

7- FINET G., HUO Y., RIOUFOL G., OHAYON J., GUERIN P. and KASSAB G.S.: Structure-function relation in the coronary artery tree: From fluid dynamics to arterial bifurcations. Euro Intervention, 6 Suppl J: J10-15, 2010.

8- WENTZEL J.J., CHATZIZISIS Y.S., GIJSEN F.J., GIANNOGLOU G.D., FELDMAN C.L. and STONE P.H.: Endothelial shear stress in the evolution of coronary atherosclerotic plaque and vascular remodelling: Current understanding and remaining questions. Cardiovasc. Res., 96: 234-43, 2012.
9- RIZIK D.G., KLASSEN K.J. and HERMILLER J.B.: Bifurcation coronary artery disease: Current techniques and future directions (part 2). J. Invasive Cardiol., 20: 135-41, 2008.

10-NAKAZAWA G., YAZDANI S.K., FINN A.V., VORPAHL M., KOLODGIE F.D. and VIRMANI R.: Pathological findings at bifurcation lesions: The impact of flow distribution on atherosclerosis and arterial healing after stent implantation. J. Am. Coll. Cardiol., 55: 1679-87, 2010.

11- MILLER J.M., ROCHITTE C.E., DEWEY M., ARBABZADEH A., NIINUMA H., GOTTLIEB I., PAUL N., CLOUSE M.E., SHAPIRO E.P., HOE J., LARDO A.C., BUSH D.E., De ROOS A., COX C., BRINKER J. and LIMA J.A.: Diagnostic performance of coronary angiography by 64-row ct. N. Engl. J. Med., 359: 2324-36, 2008

12- MICHAEL J. WOLK, STEVEN R. BAILEY, JOHN U. DOHERTY, PAMELA S. DOUGLAS, ROBERT C. HENDEL, CHRISTOPHER M. KRAMER, JAMES K. MIN, MANESH R. PATEL, LISA ROSENBAUM, LESLEE J. SHAW, RAYMOND F. STAINBACK, and JOSEPH ALLEN: A CCF/AHA/ASE/ASNC/HFSA/HRS/SCAI/SCCT/ SCMR/STS 2013 Multimodality Appropriate Use Criteria for the Detection and Risk Assessment of Stable Ischemic Heart Disease: A Report of the American College of Cardiology Foundation Appropriate Use Criteria Task Force, American Heart Association, American Society of Echocardiography, American Society of Nuclear Cardiology, Heart Failure Society of America, Heart Rhythm Society, Society for Cardiovascular Angiography and Interventions, Society of Cardiovascular Computed Tomography, Society for Cardiovascular Magnetic Resonance, and Society of Thoracic Surgeons. J. Am. Coll. Cardiol., Feb., 63 (4): 380-406, 2014.

13- MAUROVICH P., MAROS F., SZILARD V. and BÉLA M.: Comprehensive plaque assessment by coronary CT angiography. Nat. Rev. Cardiol. advance online publication; doi: 10.1038/nrcardio.2014.60.

14- STELLA-LIDA P., CHRYSAFIOS G., FRANK G., ALEXIA R., JADE O., ALINA G., JOHAN S., HECTOR G., PIM J. and JOLANDA W.: A CT-based Medina Classification in Coronary Bifurcations: Does the lumen Assessment Provide Sufficient Information? Catheterization and Cardiovascular Interventionsm 84: 445-52, 2014.

15- ERICA MAFFEI, SARA SEITUN, KOEN NIEMAN, CHIARA MARTINI, ANDREA IGOREN GUARICCI, CARLO TEDESCHI, ANNICK C. WEUSTINK, NICO R. MOLLET, ELENA BERTI, ROBERTO GRILLI, GIANCARLO MESSALLI and FILIPPO CADEMARTIRI: Assessment of coronary artery disease and calcified coronary plaque burden by computed tomography in patients with and without diabetes mellitus. European Radiology volume 21, pages 944-53, 2011.

16- SCHUIJF J.D., BECK T., BURGSTAHLER C., JUKEMA J.W., DIRKSEN M.S., De ROOS A., VAN DER WALL E.E., SCHROEDER S., WIJNS W. and BAX J.J.: Differences in plaque composition and distribution in stable coronary artery disease versus acute coronary syndromes; non-invasive evaluation with multi-slice computed tomography. Acute Cardiac Care, 9: 48-53, 2007.

17- RODRIGUEZ-GRANILLO G.A., ROSALES M.A., DEGROSSI E., DURBANO I. and RODRIGUEZ A.E.: Multislice ct coronary angiography for the detection of burden, morphology and distribution of atherosclerotic plaques 
in the left main bifurcation. The international journal of cardiovascular imaging, 23: 389-92, 2007.

18- RODRIGUEZ-GRANILLO G.A., GARCIA-GARCIA H.M., WENTZEL J., VALGIMIGLI M., TSUCHIDA K., VAN DER GIESSEN W., De JAEGERE P., REGAR E., De FEYTER P.J. and SERRUYS P.W.: Plaque composition and its relationship with acknowledged shear stress patterns in coronary arteries. Journal of the American College of Cardiology, 47: 884-5, 2006.

19- KASPERA W., CMIEL-SMORZYK K., WOLANSKI W., KAWLEWSKA E., HEBDA A., GZIK M. and LADZINSKI P.: Morphological and hemodynamic risk factors for middle cerebral artery aneurysm: A case-control study of 190 patients. Sci. Rep., 10: 2016, 2020.

20- HONG M.K., MINTZ G.S., LEE C.W., LEE B.K., YANG T.H., KIM Y.H., SONG J.M., HAN K.H., KANG D.H., CHEONG S.S., SONG J.K., KIM J.J., PARK S.W. and PArk S.J.: The site of plaque rupture in native coronary arteries: A three-vessel intravascular ultrasound analysis. Journal of the American College of Cardiology, 46: 261$5,2005$.

21- REIG J. and PETIT M.: Main trunk of the left coronary artery: Anatomic study of the parameters of clinical interest. Clinical anatomy, 17: 6-13, 2004.

22- PFLEDERER T., LUDWIG J., ROPERS D., DANIEL W.G. and ACHENBACH S.: Measurement of coronary artery bifurcation angles by multidetector computed tomography. Investigative Radiology, 41: 793-8, 2006.

23- PAPADOPOULOU S.L., BRUGALETTA S., GARCIAGARCIA H.M., ROSSI A., GIRASIS C., DHARAMPAL A.S., NEEFJES L.A., LIGTHART J., NIEMAN K., KRESTIN G.P., SERRUYS P.W. and De FEYTER P.J. Assessment of atherosclerotic plaques at coronary bifurcations with multidetector computed tomography angiography and intravascular ultrasound-virtual histology. European Heart Journal Cardiovascular Imaging, 13: 63542, 2012.

24- SUN Z. and CAO Y.: Multislice ct angiography assessment of left coronary artery: Correlation between bifurcation angle and dimensions and development of coronary artery disease. European Journal of Radiology, 79: e90-95, 2011.

25- KAWASAKI T.K.H., SERIKAWA T., et al.: The bifurcation study using 64 multislice computed tomography. Catheter Cardiovasc. Interv., 73: 653-8, 2009.

26- COLLINS N., SEIDELIN P.H., DALY P., IVANOV J., BAROLET A., MACKIE K., BUI S., SCHWARTZ L. and DZAVIK V.: Long-term outcomes after percutaneous coronary intervention of bifurcation narrowings. Am. J. Cardiol., 102: 404-10, 2008.

27- KONISHI T., YAMAMOTO T., FUNAYAMA N., NISHIHARA H. and HOTTA D.: Relationship between left coronary artery bifurcation angle and restenosis after stenting of the proximal left anterior descending artery. Coron. Artery Dis., 27: 449-59, 2016.

28- DZAVIK V., KHARBANDA R., IVANOV J., ING D.J. BUI S., MACKIE K., RAMSAMUJH R., BAROLET A., SCHWARTZ L. and SEIDELIN P.H.: Predictors of longterm outcome after crush stenting of coronary bifurcation lesions: Importance of the bifurcation angle. Am. Heart J., 152: 762-9, 2006

29- ADRIAENSSENS T., BYRNE R.A., DIBRA A., IIJIMA R., MEHILLI J., BRUSKINA O., SCHOMIG A. and KASTRATI A.: Culotte stenting technique in coronary bifurcation disease: Angiographic follow-up using dedicated quantitative coronary angiographic analysis and 12month clinical outcomes. Eur. Heart J., 29: 2868-76, 2008

30- CHEN S.L., ZHANG J.J., YE F., LIU Z.Z., ZHU Z.S., LIN S., TIAN N.L., FANG W.Y., CHEN Y.D., SUN X.W., WEI M., SHAN S.J., KAN J., QIAN J., YANG S., YUAN Z.B., KWAN T.W. and HU D.Y.: Crush stenting with drug-eluting stents: Relevance of coronary bifurcation lesion location on angiographic and clinical outcomes. Clin. Cardiol., 33: E32-39, 2010.

31- FREIXA X., ALMASOOD A.A., ASIF N., BUI S., IVANOV J., OSTEN M.D., ING D., OVERGAARD C.B., HORLICK E., SEIDELIN P.H. and DZAVIK V.: Longterm outcomes using a two-stent technique for the treatment of coronary bifurcations. Int. J. Cardiol., 168: 446$51,2013$. 


\section{زاوية تفرع الشريان التاجى فى المواقع الشريانية المختلفة وتطور آفة التفرع والتأثير النزير الهير التيرير}

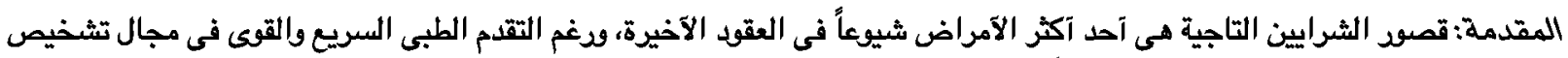

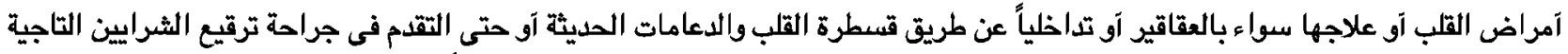

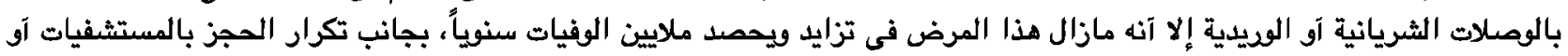
المعاناة من فثل عضلة القلب وهو في المجمل يسبب تكلفة إقتصادية آلهاية ومجتمعية عالية ومتزايدة.

تصلب الثرايين التاجية هو السبب الرئيسى لقصود الشرايين التاجية وهو ناتج لعديد العوامل الجينية والمرضية والبيئية التى تؤدى إلى إلى

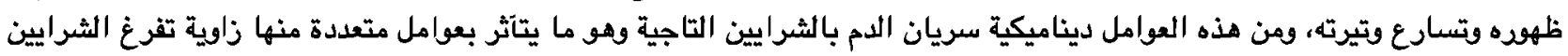

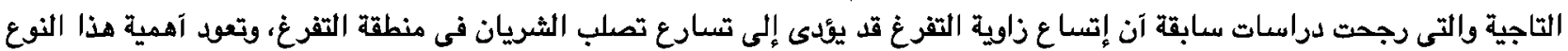

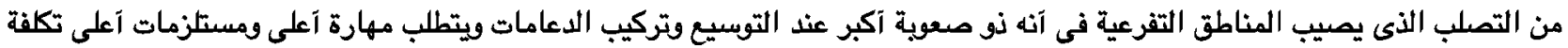

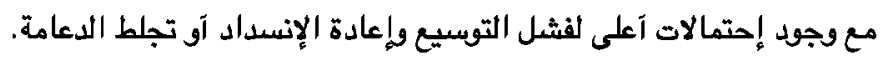

الهدف من الدراسة: محاولة معرفة علاقة زاوية تفرع الشريان التاجى فى المواقع الثريانية المختلفة وإحتمالية حدوث ضيق بهذه الآماكن وآيضاً علاقة هذه الزاوية بإحتمالية حدوث حالات متلازمة قصور الشريان التاجى الحاد خلال عام من المتابعة.

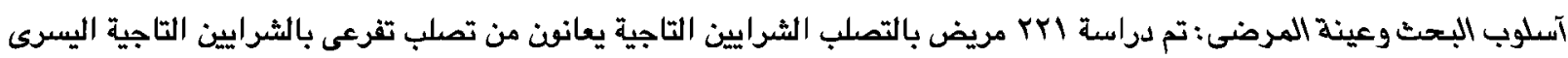

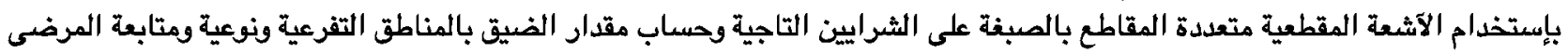

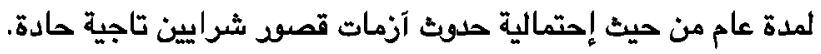

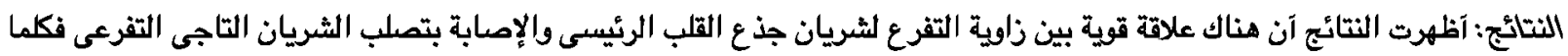

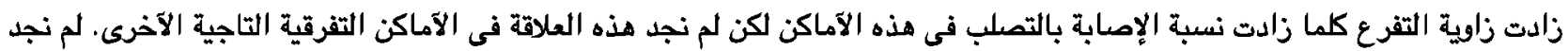

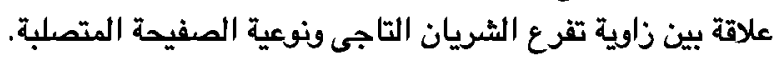
زاوية التفرع فى شريان جذع القلب كانت آكبر منها فى الشريان الآيسر الآمامى النازل آو فى الشريان الآيسر المحورى.

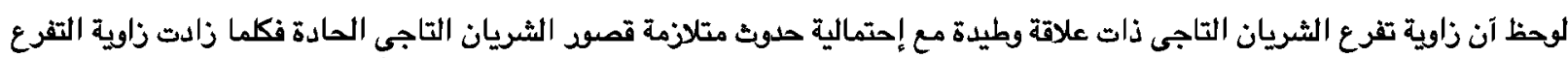

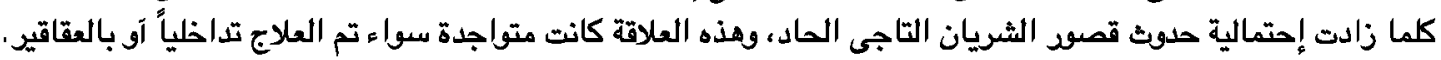

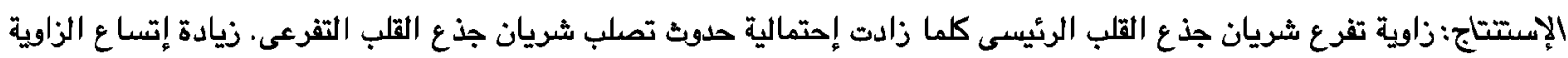

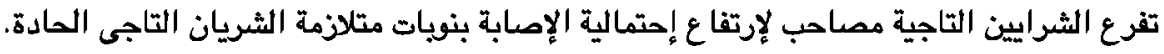

